\title{
Alkali-Silica Reactions: An Overview. Part I
}

\author{
Isabel Fernandes • Maarten A. T. M. Broekmans
}

Received: 12 June 2013/Accepted: 2 July 2013/Published online: 26 July 2013

(C) Springer Science+Business Media New York and ASM International 2013

\begin{abstract}
Concrete is one of the most widely used building materials since the nineteenth century. The manufacture of concrete includes the binder (cement), aggregates, water and possible additives. Although very versatile and durable, in the early 1900s, it was recognized that concrete can deteriorate and in consequence, compromise the durability and good functioning of the structures. From the many different damage mechanisms that can originate the deterioration of concrete, alkali-silica reaction (ASR) is the one that involves the aggregates. Aggregates constitute about three-quarter of the volume of concrete, and therefore their physical and chemical properties need to be correctly assessed before their use in concrete. Since the 1940s, considerable research has been developed to determine which components of the rocks and minerals contribute to the chemical reaction involved in this process of deterioration. However, a lot still remains to be understood. In the present article, an introduction to the subject is made, focusing mainly on the mechanisms and on the manifestations of the ASR.
\end{abstract}

Keywords Building materials · Corrosion - Processes

I. Fernandes $(\square)$

DGAOT/Centro de Geologia, University of Porto,

Porto, Portugal

e-mail: ifernand@fc.up.pt

M. A. T. M. Broekmans

Geological Survey of Norway - NGU, PO Box 6315,

Sluppen, 7491 Trondheim, Norway

\section{Introduction}

Modern-day concrete is the most widely applied building material, with global production exceeding 9.5 billion cubic metres, or about 22 billion tonnes. The manufacture of modern concrete includes ordinary Portland cement (OPC) binder, coarse and fine aggregates, water for hydration, and organic additives to control workability and flow properties. Concrete presents architects nearly total form freedom by virtue of the mouldable qualities of freshly mixed concrete, while hardened concrete unifies bulk strength and durability in a single material.

Concrete was already used extensively by the Romans over 2000 years ago, then known as 'opus camentitium' [1, 2]. Many monumental Roman concrete structures survive even today in Rome and elsewhere across Europe (e.g. [3]) in an amazingly good state, demonstrating detailed understanding of structural concrete engineering as well as material properties [4]. In the oldest types of concrete, the binder consists of burnt lime $(\mathrm{CaO})$, produced from calcium-carbonate rock (e.g. chalk, limestone) by high-temperature calcination. The burnt lime is quenched with water before it is mixed with sand to make mortar. Setting and hardening occurs by uptake of $\mathrm{CO}_{2}$ from the air to form carbonate again.

By mixing lime with fine-grained particles of volcanic tuff from Pozzuoli near the town of Naples, the Romans invented pozzolanic (sic!) cement, and by using large porous particles of the same tuff for aggregate, they developed lightweight concrete. Unknowingly, the pozzolanic binder consisted of aluminous hydrated calcium-silicate hydrate, and has proven capable to resist exposure to seawater for over two millennia [5].

The invention of Portland cement is generally attributed to Joseph Aspdin, who in 1824 acquired a patent to a 
'superior cement resembling Portland stone,' a then popular natural dimension stone for which he sought an alternative that was easier to shape and form (see e.g. [6]). His son William Aspdin burned carbonate-clay mixtures at temperatures over $1250{ }^{\circ} \mathrm{C}$ and became the first to create cement containing alite (see later). However, it was only through contributions of contemporaries Louis Vicat (chemistry) and Isaac Johnson (clinkering sensu stricto) that production of Portland cement could be industrialized from per-batch in a lime kiln into a continuous process using a rotary kiln.

Today, Portland clinker is made by calcination of a mixture of powdered limestone, clay and other mineral materials (i.e. the 'raw meal') in a rotary kiln at a temperature of about $1450{ }^{\circ} \mathrm{C}$ [7]. The composition of the raw meal is carefully balanced to obtain a particular bulk composition. As the material rolls down the kiln towards high temperature end, it gradually releases volatiles and transforms into clinker minerals, and partially melts producing clinker nodules. The clinker nodules are air-quenched and finely interground with a few per cents of gypsum or anhydrite ('sulphate') to make OPC (e.g. [8]). Designation and detailed composition of the final cement product may vary slightly from country to country, e.g. UK-(formerly)OPC, USA-Type I Portland cement, and EU-CEM I.

The main oxide constituents of Portland cement clinker are presented in Table 1 [8-10]. A range of additional constituents have been identified, depending on minor and trace oxide compositions of the actual raw meal and fuel, as well as kiln conditions.

According to EN 206 [12], concrete is a '[composite] material formed by mixing cement, coarse and fine aggregate and water, with or without the incorporation of admixtures and additions, which develops its properties by hydration of the cement."

The hydration of Portland cement is a complicated process involving formation of new product phases as well as decomposition and consumption of temporary intermediate phases. Modern instrumentation and analytical methods enable in situ analysis of hydration progress [13].

Upon addition of water, aluminate and ferrite hydrate instantly, in the presence of sulphate-producing (primary) ettringite. The ettringite armours the aluminate/ferrite

Table 1 Main constituents in Portland clinker

\begin{tabular}{lll}
\hline Constituent & Oxide composition & $\mathrm{CCN}$ shorthand \\
\hline Alite & $3 \mathrm{CaO} \cdot \mathrm{SiO}_{2}$ & $\mathrm{C} 3 \mathrm{~S}$ \\
Belite & $2 \mathrm{CaO} \cdot \mathrm{SiO}_{2}$ & $\mathrm{C} 2 \mathrm{~S}$ \\
Aluminate & $3 \mathrm{CaO} \cdot \mathrm{Al}_{2} \mathrm{O}_{3}$ & $\mathrm{C} 3 \mathrm{~A}$ \\
Ferrite & $4 \mathrm{CaO} \cdot \mathrm{Al}_{2} \mathrm{O}_{3} \cdot \mathrm{Fe}_{2} \mathrm{O}_{3}$ & $\mathrm{C} 4 \mathrm{AF}$
\end{tabular}

a 'Cement chemist notation': $\mathrm{CaO}=\mathrm{C} ; \mathrm{SiO}_{2}=\mathrm{S} ; \mathrm{Al}_{2} \mathrm{O}_{3}=\mathrm{A}$; $\mathrm{Fe}_{2} \mathrm{O}_{3}=\mathrm{F}$; also see [11] preventing further hydration, thus regulating setting. This so-called dormant period allows for transport, placement and compaction of the fresh concrete mix at the construction site. After a few hours, hydration of $\mathrm{C} 2 \mathrm{~S}$ and $\mathrm{C} 3 \mathrm{~S}$ kicks in and produces calcium-silicate-hydrate (CSH), consisting of various inosilicates with chain length and degree of polymerization generally increasing with age. Portlandite $\left(\mathrm{Ca}[\mathrm{OH}]_{2}\right)$ is the main by-product, and represents the main pH-buffer in hydrated Portland cement pastes. Even when solubility is low, portlandite is the better soluble paste constituent relative to $\mathrm{CSH}$. Some of the portlandite is consumed by the ettringite dissolving the aluminate/ferrite's armour, after which setting proceeds, and the concrete mix develops its final strength.

Supplementary cementitious material (SCM) is the general denominator for a group of materials comprising pozzolanas of artificial or natural origin, e.g. fly ash, silica fume, blast-furnace slag, metakaolinite and calcic zeolite (see e.g. [14]). SCMs may act as inert filler occupying the smallest interstices in the hydrated paste, or chemically react with excess portlandite to form additional $\mathrm{CSH}$ binder, but usually combine both qualities, producing a denser and stronger binder.

Durability of concrete is determined by its ability to resist weathering and alteration from exposure to weather and climate (e.g. frost, freeze/thaw cycling, hot sunshine/ cool rain shower etc.), attack from exposure to aggressive chemicals (e.g. deicer, seawater, acid/base solutions, soft condensate water etc.), as well as mechanical wear (e.g. impact, abrasion etc.) [15]. Attack mechanisms often work synergistically, thereby accelerating decay and deterioration.

Concrete durability research has focused on identification and characterization of concrete constituents, exposure conditions, correct diagnosis and gradation of observed damage, effective and durable remediation and repair, as well as prevention. Proper identification of primary and secondary causes of deterioration is essential to determine adequate rehabilitation strategies, and to prevent future damage [16].

\section{Main Causes of Deterioration}

Deterioration of concrete can be caused by a number of principally different mechanisms. According to Hobbs [17], the most common causes of deterioration are the following:

(a) freeze/thaw cycling,

(b) carbonation,

(c) chloride penetration,

(d) sulphate attack, and

(e) Alkali-aggregate reaction (AAR). 
Examination of deteriorated concrete structures often reveals more than one mechanism to be active. For instance, cracks induced by freeze/thaw cycling provide access to the structure's interior for hydrous solutions carrying deicer.

Freeze/thaw cycling is a primarily mechanical type of deterioration, caused by the step-wise volume increase of liquid water freezing in pores and voids within the concrete. Upon further cooling, the ice shrinks faster than the surrounding concrete creating space, which is filled by additional water vapour condensing on the ice. When the temperature rises, the ice expands faster than the concrete, inducing additional cracking (e.g. [18]) and leading to scaling and spalling. This process is mainly restricted to temperate and arctic areas of the world.

Carbonation is an acid-base neutralization reaction, with atmospheric $\mathrm{CO}_{2}$ initially reacting with portlandite $\mathrm{Ca}[\mathrm{OH}]_{2}$ in the cement paste to precipitate $\mathrm{CaCO}_{3}$ (i.e. the 'carbonate') and $\mathrm{H}_{2} \mathrm{O}$. The scavenged $\mathrm{OH}^{-}$in the concrete pore solution is replenished by dissolution of new portlandite until it is exhausted. The initial concrete pore water $\mathrm{pH}$ of $\sim 14$ then drops to $\sim 10$, depassivating reinforcement steel and initiating corrosion (e.g. [19, 20]). Steel corrosion products from carbonation precipitate in situ and cause the concrete cover to spall off, signalling the problem.

In structures exposed to seawater or deicing salts, chloride ions may penetrate the cover by diffusion or via capillary suction even through thin cracks, and reach the steel reinforcement. Apart from carbonation, where dry/ wet cycling is needed to effectively carbonate the paste, chloride-induced corrosion can occur in wet-saturated conditions. The chloride corrosion product $\left(\mathrm{FeCl}_{3}\right)$ is water-soluble and does not precipitate locally, thus no cracking or spalling occurs. However, brownish bleeding stain from corrosion product precipitated on the structure's outer surface may occasionally serve as an indicator. Chloride-induced corrosion is very much localized (as opposed to carbonation), and steel rebars may appear as if cut with a hacksaw [21]. Chloride has been shown to penetrate via poorly covered pre-tensioning anchors along steel strands inside cable ducts, to an extent of tens of metres into the structure, where it is extremely difficult to locate [22].

The use of steel (e.g. pre-/post-tensioned, traditional reinforcement) in concrete structures has the primary function to enhance tensile strength, allowing much larger spans than would be possible with nonreinforced concrete. Corrosion of steel reinforcement has several consequences. Corrosion-induced cracking, spalling, delamination and bleeding do decay the aesthetic aspect of a structure, giving it a 'poorly maintained' appearance (Fig. 1). However, far more important than cosmetic appearance is the reduction of the cross-sectional area of the steel and concomitant reduction of load-bearing capacity $[9,21]$.

Sulphate attack is caused by chemical alteration of the cement paste resulting from dissolved $\mathrm{SO}_{4}$ [23]. Sulphate may originate externally from various sources, or internally from the gypsum added to control the time for setting. The mechanism known as 'delayed ettringite formation' is caused by excess temperature of $>70{ }^{\circ} \mathrm{C}$ during setting of the concrete mix. At this high temperature, sulphate is initially incorporated with the forming CSH paste, from which it is expelled again upon maturation. Secondary ettringite precipitates, the paste expands and detaches from aggregate (Fig. 2), and the concrete loses its strength and ultimately disintegrates (e.g. [24]). Alternatively, sulphate dissolved in ground water, seawater, sewage, or industrial solutions may infiltrate the paste in a mechanism known as 'thaumasite-form of sulphate attack' (TSA). Also TSA leads to extensive cracking, expansion and progressive loss of concrete strength until disintegration, with alteration of paste composition and precipitation of gypsum $\left(\mathrm{CaSO}_{4}\right.$. $\left.2 \mathrm{H}_{2} \mathrm{O}\right)$, ettringite $\left.\left[\mathrm{Ca}_{3} \mathrm{Al}(\mathrm{OH})_{6} \cdot 12 \mathrm{H}_{2} \mathrm{O}\right]_{2} \mid\left(\mathrm{SO}_{4}\right)_{3} \cdot 2 \mathrm{H}_{2} \mathrm{O}\right]$ and/ or thaumasite $\left.\left[\mathrm{Ca}_{3} \mathrm{Si}(\mathrm{OH})_{6} \cdot 12 \mathrm{H}_{2} \mathrm{O}\right]_{2} \mid\left(\mathrm{SO}_{4}\right)_{3} \cdot\left(\mathrm{CO}_{3}\right)_{2}\right]$, often associated with 'popcorn calcite deposition' $[25,26]$.

The following will be focused on AAR, which is the main subject of the present article.

\section{The AAR}

In 1923, a number of concrete structures in the USA were observed to develop severe cracking, with unidentified cause. In 1940, Stanton recognized for the first time alkalis, $\mathrm{Na}$ and $\mathrm{K}$, in the paste combined with silica from the

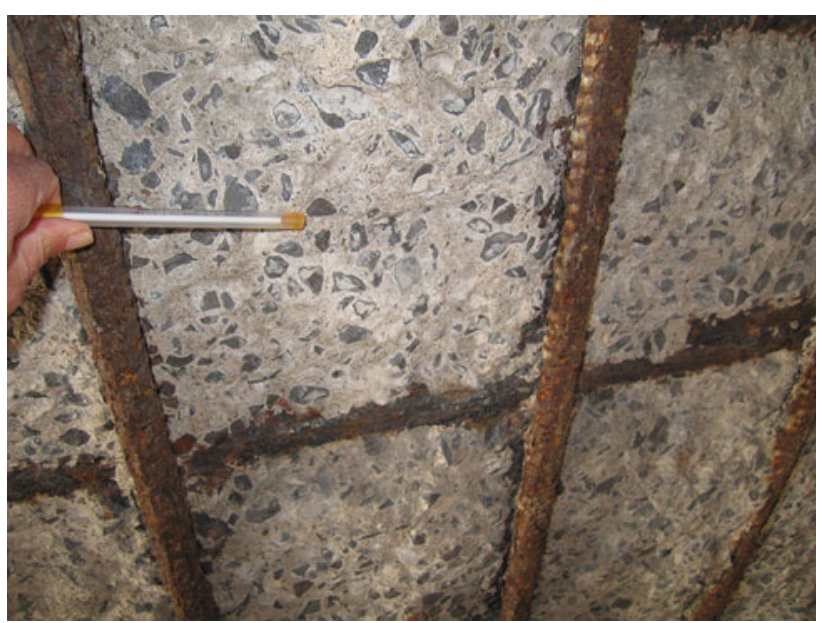

Fig. 1 Corrosion of the steel bars and spalling of the concrete in a viaduct 

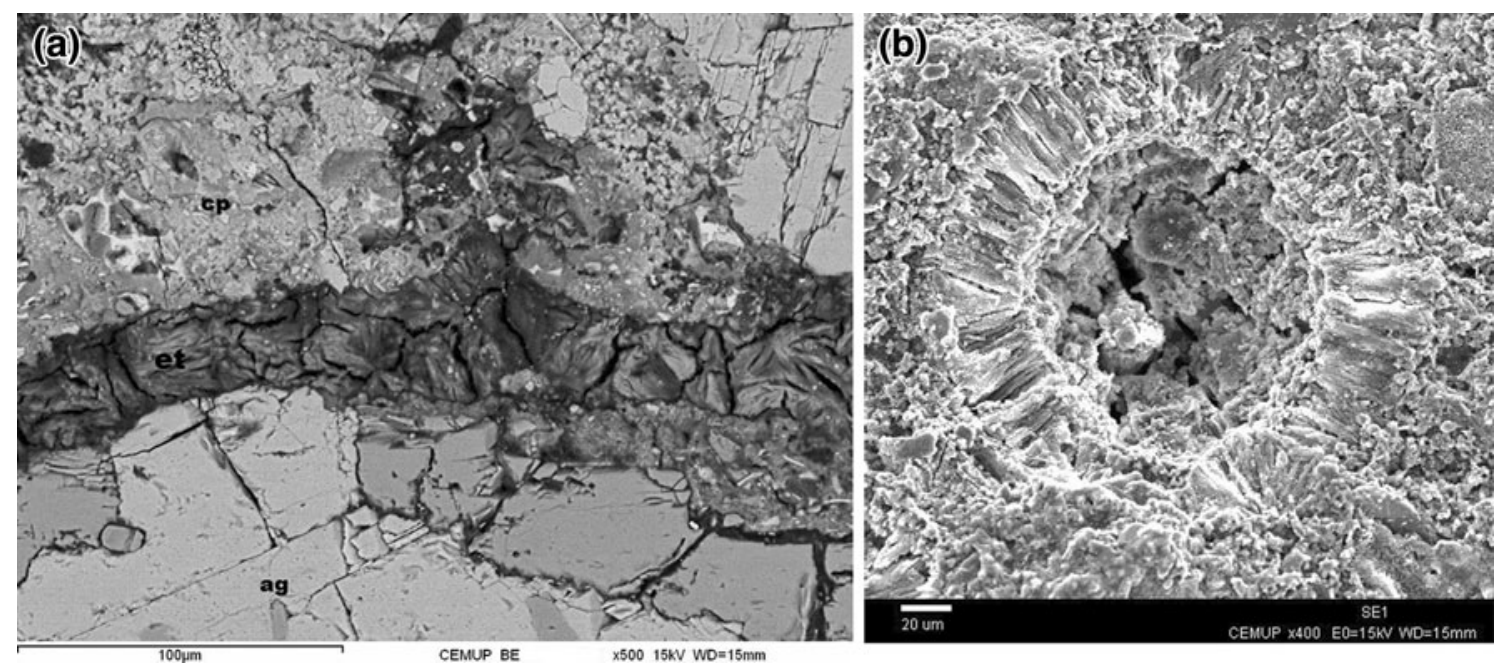

Fig. 2 Images of ettringite crystals obtained by scanning electron microscope (SEM): (a) ettringite in cracks inside concrete, between the aggregate $(a g)$ and the cement paste $(c p)$ in a polished thin section; (b) ettringite inside a void in a fragment of concrete

aggregate, in a deleterious reaction dubbed 'alkali-silica reaction' (ASR) (see [27, entry 1008]).

Since its original discovery, deleterious ASR has been recognized in many concrete structures, and it is a worldwide problem in concrete technology [28, 29]. Alkaliaggregate reaction, commonly known as AAR, is the chemical reaction in either mortar or concrete between the hydroxyl $\left(\mathrm{OH}^{-}\right)$ions associated with alkalis, sodium (Na) and potassium $(\mathrm{K})$, naturally present in Portland cement, or from alternative sources with 'reactive silica' present in coarse or fine aggregate. Two main types of AAR are distinguished, notably ASR and alkali-carbonate reaction. The so-called alkali-silicate reaction is now considered a slow/late type of ASR [30]. Deleterious AAR is generally slow to become apparent, in temperate and arctic regions often after 20-30 years, while earlier in warmer climes. Exposure to severe conditions (e.g. freeze/thaw cycling, deicers, seawater) usually accelerates development of AAR damage and decay.

The most common type of AAR involves amorphous, disordered or poorly crystallized silica in the aggregate, exposed to the concrete interior at $\mathrm{pH} \sim 14$. This reaction is called ASR and initially forms a hygroscopic alkalisilica gel (e.g. [17, 31]). Owing to hydraulic reaction with water, the gel expands and exerts swelling pressures inside the reactive aggregate particle, which are sufficient to induce and propagate fractures. Deleterious ASR will only occur if the following three conditions are simultaneously fulfilled $[15,16,32]$ :

1. The presence of sufficient fluid. Water is essential as a transport medium for the dissolved species, as well as for alkali-silica gel to absorb and expand [33]. The water content in ASR-affected structures is normally expressed as relative humidity (RH). The critical limit for developing ASR is reported to lie in the range of 80-90\% RH depending on several factors [34]. For ordinary concrete, part of the original mixing water is usually available for a prolonged period, even in dry service conditions.

2. Sufficient availability of alkalis. The alkali content (Na or K) of the pore fluid is of key importance for the development of ASR. First, the presence of Na and $\mathrm{K}$ invokes the dissolution of portlandite $\mathrm{Ca}[\mathrm{OH}]_{2}$ to balance the increased alkali with $\mathrm{OH}^{-}$. This higher alkalinity enhances dissolution of reactive silica $\left(\mathrm{SiO}_{2}\right)$ from alkali-reactive aggregates. Second, $\mathrm{Na}$ and $\mathrm{K}$ react with the dissolved silica and precipitate as alkali-silica gel [15]. OPC normally contains small amounts of $\mathrm{Na}$ and $\mathrm{K}$ as sulphates, inherited from the raw meal used for clinkering, notably the clay to adjust Al-content, and coal fuel to fire the rotary kiln.

It has become a standard practice to express alkali content in terms of 'sodium equivalent'. This correlates $\mathrm{Na}$ and $\mathrm{K}$ as oxides in terms of molecular proportions as follows:

$\mathrm{Na}_{2} \mathrm{O}_{\text {equivalent }}[\mathrm{wt} \%]=\mathrm{Na}_{2} \mathrm{O}[\mathrm{wt} \%]+0.658 \mathrm{~K}_{2} \mathrm{O}[\mathrm{wt} \%]$.

The constant 0.658 represents the atomic mass ratio of $\mathrm{Na}_{2} \mathrm{O}(62.0 \mathrm{~g} / \mathrm{mol})$ over $\mathrm{K}_{2} \mathrm{O}(94.20 \mathrm{~g} / \mathrm{mol})$, which tacitly assumes identical behaviours of $\mathrm{Na}$ and $\mathrm{K}$ under prevailing conditions in ASR concrete (see e.g. [35]).

Many concrete structures diagnosed with ASR deterioration were constructed using high-alkali cement containing $>1.00 \mathrm{wt} \% \mathrm{Na}_{2} \mathrm{O}_{\text {eq }}[33,36]$. A limit to alkali content of $0.60 \mathrm{wt} \% \mathrm{Na}_{2} \mathrm{O}_{\mathrm{eq}}$ has often been used for Portland cement 
in specifications to minimize deterioration of concrete when reactive aggregates are used [16]. Nevertheless, some structures built with an alkalis content below this limit still develop significant damage [37-41]. Tuthill [40] suggested that a limit of $0.40 \% \mathrm{Na}_{2} \mathrm{O}_{\text {equivalent }}$ should be adopted.

Besides the alkalis from the cement, some $\mathrm{Na}$ and $\mathrm{K}$ may derive from the aggregates themselves [28]. Some common rock-forming minerals (e.g. micas, feldspars, clays etc.) contain substantial alkali that may be released from their structures upon prolonged exposure to concrete conditions [38, 42-49]. Aggregates containing volcanic glass such as rhyolites, basalts, and andesites may also release alkalis. Alkalis from external sources such as deicing salts, seawater, groundwater and water from industrial processes, may also increase expansion caused by ASR. A more elaborate overview is given elsewhere [29].

3. The aggregate must be ASR-reactive. The most common crushed rocks, sands and gravels used as aggregates contain different forms of silica that can react with the alkalis in the pore water of concrete. Aggregates containing silica that presents large surface areas for reaction-poorly crystalline, many lattice defects, amorphous, glassy, microporous-are susceptible to reaction. Forms of silica, such as glasses, microcrystalline and crypto-crystalline quartz, in addition to opal, chalcedony, tridymite and cristobalite, are all reactive to various degrees. Straining of larger quartz grains with recrystallization and development of microcrystalline quartz may well be reactive [28, 36]. The reaction produces alkali-silica hygroscopic gel which imbibes water and swells causing distress in the concrete.

The development of a deleterious ASR can be prevented by eliminating at least one of the three prerequisites described above, and for critical structures, at least two. This can be achieved, for instance, by selecting a particular concrete composition, cement type, or aggregate, which ultimately prevents the exposure to humidity.

\section{ASR Mechanisms}

The chemical reaction involved in ASR is essentially the dissolution of silica in an alkaline solution at high $\mathrm{pH}$. The structure of quartz $\left(\mathrm{SiO}_{2}\right)$ is composed of three-dimensionally linked $\mathrm{O}_{2}-\mathrm{Si}-\mathrm{O}_{2}$ silica tetrahedra sharing their apical oxygens. However, the detailed structure at the surface is different with unsatisfied charges and loose bonds, especially in poorly crystalline silica. Dissolved hydroxyl $\mathrm{OH}^{-}$attaches to unsatisfied siloxane bonds ( $\mathrm{Si}-$ $\mathrm{O}-\mathrm{Si}$ ) present at the silica surface, forming silanol ( $\mathrm{Si}-\mathrm{OH})$ groups. Though several models for the actual dissolution process have been proposed, the fine details are still subject to extensive discussion and research. A summary is given in the study by Broekmans [29, 305ff].

ASR is generally classified into two subgroups $[30,50$, 51]:

1. The fast ASR was identified first, and it is generally the most rapid type of AAR. It occurs with some forms of silica, a few of them being hydrous. This 'classical' type of ASR includes rocks as chert containing opal and chalcedony;

2. The slow/late expanding alkali-silicate/silica reaction [52]. The alkali-reactive rocks classified in this group are generally crystalline, quartz-bearing rocks. In many of these rocks, strained quartz is believed to be the reactive component.

The term alkali-silicate reaction used to be applied to designate the reaction involving aggregates from rocks such as phyllites, argillites and certain greywackes which contain phyllosilicates (e.g. vermiculite, chlorite and mica) [28]. However, the expansion with these rocks seems to be caused by the presence of finely divided silica, which is also ASR. These rocks are actually included in slow/late potentially reactive rocks.

\section{Manifestations of Deterioration due to ASR}

The acceptance of ASR as a deleterious mechanism in concrete structures occurred during the twentieth century at different times in several countries. For example, it was accepted as a matter to be studied in the UK in 1971 [53, 54], in Germany in 1960, in France in 1976 [55, 56], and in Japan in 1983 [57]. In New Zealand, ASR has been considered an issue since 1943 [58]. Some countries, such as the Netherlands, denied the occurrence of ASR for decades until it became very evident, mainly in viaducts [59].

The most evident manifestations of deleterious ASR in a concrete structure comprise concrete cracking, displacement of structural members, pop-outs and the presence of gel in fractures, or associated with aggregate particles within the concrete $[15,16,36,53,60,61]$. The most vulnerable parts of a concrete structure are those exposed to a warm and humid environment. Field experience indicates that concrete exposed to repeated drying and wetting cycles is more likely to develop expansion because of ASR than concrete stored with uniform moisture content [15]. The internal expansion is a consequence of the absorption of water by the gel, which leads to the generation of tensile stresses sufficiently large such that the tensile strength of the concrete is exceeded. The cracks initiate structural damage and affect the service life of the structure. The progressive deterioration requires costly repair and 
rehabilitation of the structures to maintain their intended function $[15,16,30]$.

Although no structure is known to have collapsed because of the occurrence of ASR (at least in published documentation), there are some structures that have been demolished and replaced by new ones because the structural integrity revealed that safe operation had been severely compromised. There are examples from different locations around the world, such as the Charrest viaduct in Quebec, Canada (Fig. 3), Alto Ceira dam, in Portugal and some viaducts in the Netherlands and Belgium [59].

In the report of the British Cement Association (BCA) [60], a logical sequence for investigation of a structure, aiming at the diagnosis of ASR and assessing its impact on a structure, is proposed. The procedure includes the following steps: (1) site inspection and testing, (2) sampling, (3) laboratory investigation, (4) evaluation, and (5) risk assessment of future reactions. The report emphasizes the need to pay particular attention to critical areas, such as those exhibiting greater damage or deterioration, locations important for structural stability and safety, or areas subject to unusually severe exposure. Usually, the site inspection includes visual observations, during which the manifestations of ASR above referred are registered, are photographed, drawings are prepared and in situ tests performed.

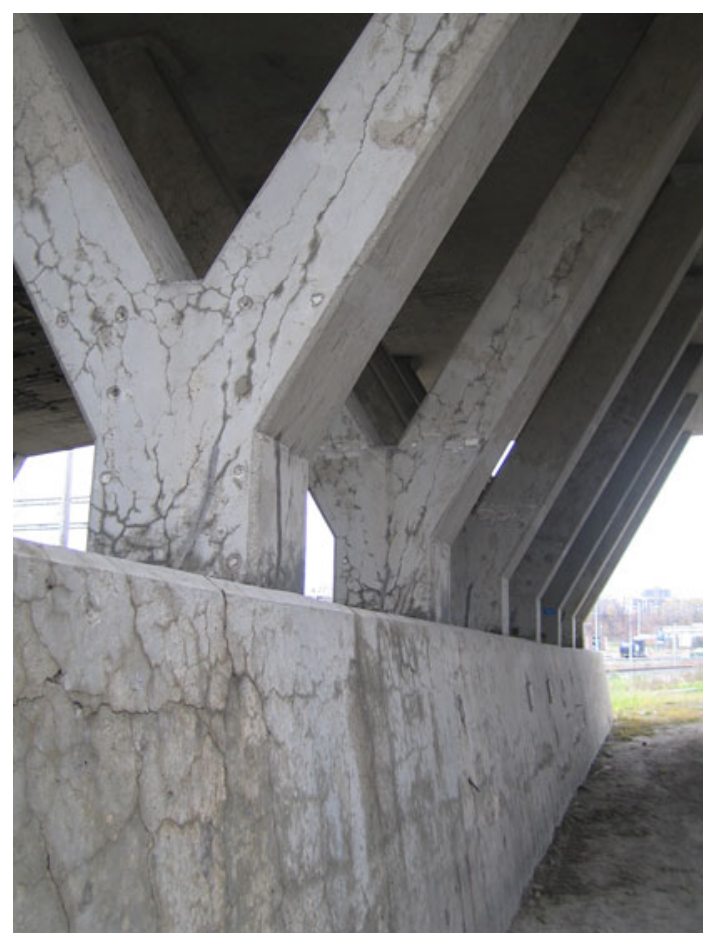

Fig. 3 Du Vallon-Charest highway interchange viaduct, in Quebec city, Canada, recently demolished because of ASR
Cracking

It is not unusual for concrete structures to show some cracking which may originate from different mechanisms, including plastic shrinkage, drying shrinkage, early-age thermal contraction, frost attack, corrosion of steel rebars, and loading. Less common causes of cracking are sulphate attack and ASR [16, 60]. The cracks do not usually affect structural integrity, but they become facilitators for access of weathering factors to the interior of concrete. Cracking becomes evident when calcium hydroxide leaches out or after a rainfall, as concrete dries unevenly, and the fine lines of the cracks become more prominent.

The cracks which originate from ASR are a consequence of swelling from the uptake of water by ASR gel. This cracking is characterized by a network of fine cracks joined up in polygonal shapes and confined by larger cracks in a pattern that resembles the limits in a map and is named 'map cracking'. This random distribution occurs in unrestrained concrete $[16,53,61]$. Because the least restraint occurs in a direction perpendicular to the surface, the cracks tend to align subparallel to the surface [15]. These cracks usually do not go deeper than $25-50 \mathrm{~mm}$ of the exposed surface, seldom exceeding depths $>100 \mathrm{~mm}$ in massive structures $[16,17,61]$. In reinforced concrete, the cracks often reflect the pattern of the underlying steel (Fig. 4) and seldom go below the level of the reinforcement. In heavily reinforced, or prestressed beams and columns, or where there is longitudinal compressive stress in the structural element, cracks will tend to be orientated along the stress direction, i.e. along the length of the member and may extend along its entire length.

During field inspection, a record should be made of the position, disposition and pattern of cracking, and its extent and severity in each of the elements inspected. Photographs are usually very useful as well as scale drawings with reference to the length, width and pattern.

The width of surface macrocracks generally varies from 0.05 to $10 \mathrm{~mm}$. The measurements of crack widths on deteriorated concrete members can be used to monitor the progress of damage between visual condition surveys [16]. The width tends to increase with the development of ASR. In the early stages, slow developing ASR tends to increase the magnitude of pre-existing cracking before its magnitude reaches a level $(0.4-0.6 \mathrm{~mm} / \mathrm{m}$ free expansion) at which the strains from ASR exceed those from other causes of cracking [30].

In concrete structures, cracking develops mainly in areas where the concrete has a permanent supply of moisture, such as close to the waterline in piers, from the soil behind retaining walls, beneath pavement slabs, or by wick action in piers or columns [16]. In pavements, ASR cracks are usually perpendicular to transverse joints, and parallel to 

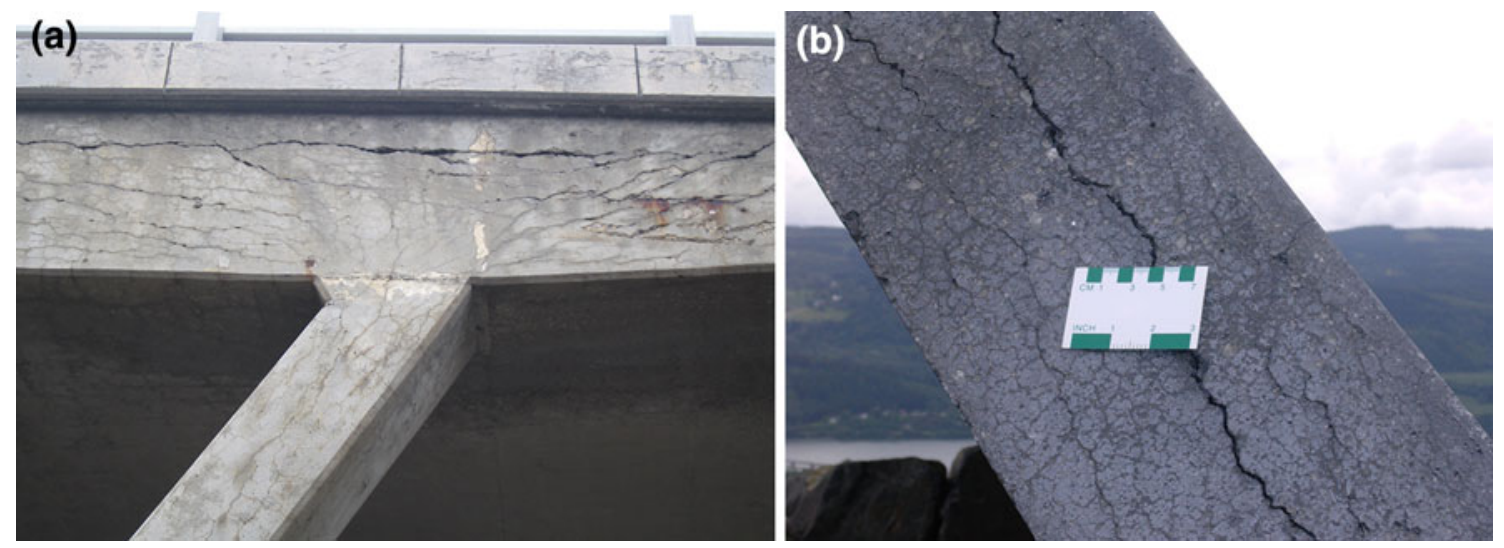

Fig. 4 Pattern of the cracks related to ASR. In both structures $(\mathbf{a}, \mathbf{b})$, the major cracks reflect the underlying steel reinforcement. Cracks tend to develop longitudinally parallel to the direction of dominant restraint

free edges along the roadside where there is less restraint. In gravity dams, expansion is less restrained in the upward direction, and cracking is mainly horizontal.

In order to obtain a quantitative assessment of the extent of cracking in structural members, the cracking index (CI) is applied. It is a crack-mapping process that consists of measurement and summation of crack widths along a set of lines drawn perpendicularly (i.e., parallel and perpendicular to the main restraint(s)) on the surface of the concrete element investigated. Further information on CI can be found in another study [16].

\section{Movements and Displacements}

Significant movements in the structure can sometimes occur because of loading, shrinkage, variable expansions, displacements and deformations (such as deflection and bulging) at different scales between parts of a structure. ASR is a potentially expansive mechanism, so that significant movements in the structure can sometimes occur [60]. A record should be made of any differential movement, such as the closing of joints, the relative displacement of adjacent concrete sections (Fig. 5), excessive deflection, and the twisting or bulging of originally flat surfaces. The volume increase may lead to malfunctioning of the structures as occurs in some spillway gates in damaged concrete dams [15].

\section{Discoloration and Dark Patches}

Distinctive surface discoloration is sometimes a feature of ASR and often borders the cracks in ASR-affected concrete. Areas along cracks may be bleached, pinkish, or brownish in colour, extending several millimetres from the crack. The lines of fine cracks may be marked by a dark discoloration, giving the appearance of permanent dampness. Severely affected areas of concrete may also develop
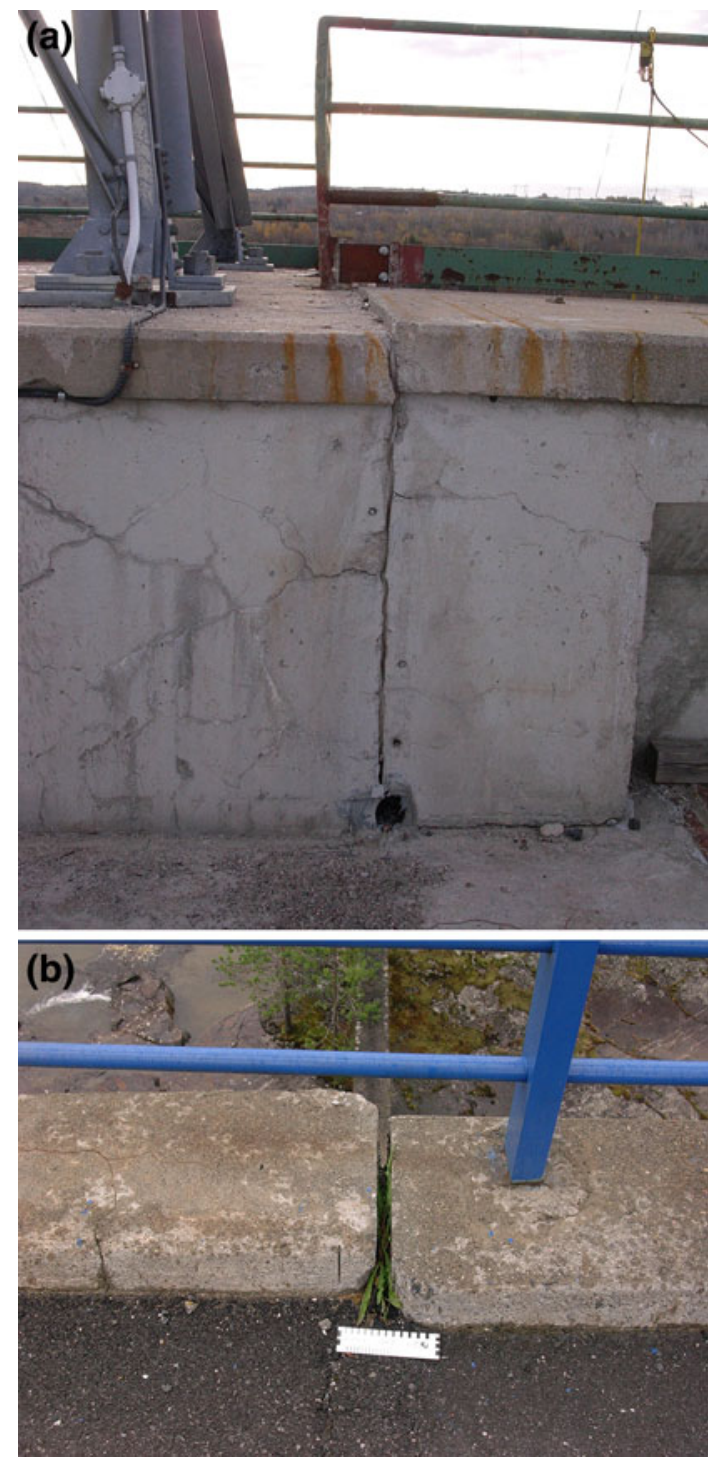

Fig. 5 Misalignment in the crest of two different concrete dams $(\mathbf{a}, \mathbf{b})$ 
patchy surface discoloration and reacted particles sometimes exhibit dark waxy rims that indicate ASR gel, either inside the particle, or along the edges of the particle.

However, discoloration may also occur for several other reasons, for example, leaching, algae growth, and reinforcement corrosion ('rust'). Examples of the extent of surface discoloration are most easily recorded by colour photography $[15,16,60,61]$.

\section{Efflorescence and Exudations}

Efflorescence is due to the transport of fluids through concrete and evaporation at the surface with the consequent deposition of salts from the solution. The most common efflorescence is formed by calcite, brucite (magnesium hydroxide), gypsum and trona. The extent, location and quantity of efflorescence should be recorded, and the colour, texture, dampness and hardness of the deposit described [16, 60]. Samples should be collected for chemical analysis in the laboratory to determine if ASR gel is present (Fig. 6).

Exudations of alkali-silica gel reflect the fact that there is enough moisture to transport the gel to the surface [62]. The exuded gel is usually transparent but it can be white, yellowish, or colourless, and viscous, fluid, waxy, rubbery, or hard. It carbonates very easily and becomes white to yellowish, and therefore difficult to distinguish from calcium carbonate deposits, which are quite common in concrete surfaces. The presence of alkali-silica gel on the surface of the concrete indicates the presence of ASR, but it does not mean that the reaction is deleterious [60].

Although surface gel exudation is characteristic of ASR, the presence of surface deposits is not necessarily indicative of ASR as other mechanisms (such as frost action or the movement of water through cracked concrete members) can also cause surface deposits without the present of ASR gel [16].
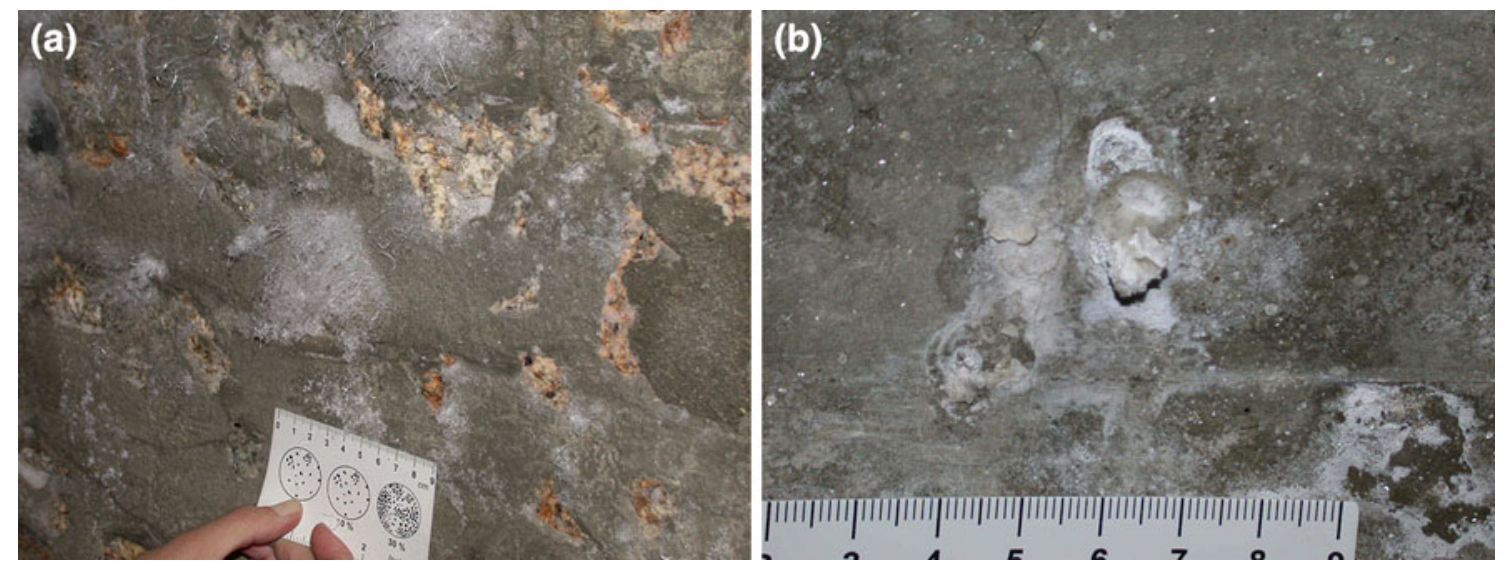

Fig. 6 Interior wall in two different dams. (a) Needle crystals of trona forming efflorescence (white fluffy patches); (b) exudation of carbonated alkali-silica gel (white droplet)
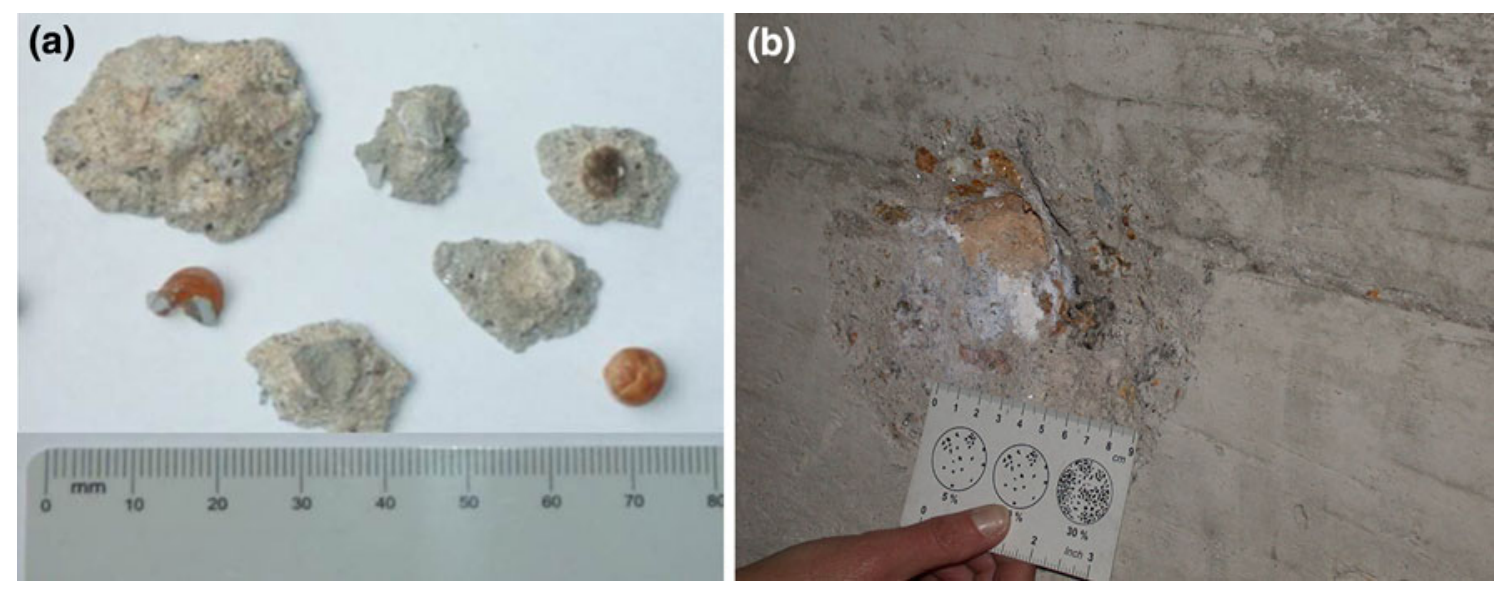

Fig. 7 Examples of pop-outs: (a) conical fragments from a pavement; (b) depression left on the wall of a concrete dam after the detachment of a pop-out 
Pop-outs

The term pop-out is applied to designate small conical fragments (Fig. 7a) which detach from the surface of the concrete because of expansion of individual aggregate particles close to an exposed concrete surface. The process leaves a shallow depression (Fig. 7b). Pop-outs can originate from ASR but also, for example, by the expansion of individual frost-susceptible water-saturated aggregate particles lying near the surface [15, 16, 60, 61]. Pop-outs can also be caused by a poor bond between the cement paste and dusty coarse aggregate particles. The number, size, and location of pop-outs should be recorded, and the nature of the aggregate exposed in the base of the pit should be identified, as these data provide valuable information about the quality of aggregates in a concrete. The confirmation of the occurrence of ASR can be made if ASR gel is present partially replacing the reactive aggregate particle. Pop-outs are a cosmetic issue but usually do not affect the serviceability or durability of the concrete.

Drawings are commonly used to illustrate the extent and severity of each feature. These drawings will assist in correlating the observed features and in locating areas for detailed inspection, and in selection of sampling locations [16].

\section{Conclusions}

AAR has been known since the early 1940s. Since then, intense research has been undertaken to understand the mechanisms involved. The most common is the reaction involving reactive forms of silica (ASR) exposed to the extremely aggressive basic environment in the interior of the concrete structures.

ASR manifestations are, in the first approach, macroscopic. The expansive reactions are manifest as severe cracking, and in some cases misalignment of structural elements. Although there are no reported examples of collapse of concrete structures due to ASR, a few have already been demolished all over the world, and replaced with new structures. Site inspection is crucial for the identification of the cause of deterioration in a concrete structure but must be complemented by laboratory tests, namely by concrete petrography, which permits the correct identification/confirmation being made of ASR.

Further discussion on ASR involves the choice of the materials to be applied to prevent the occurrence of the reaction. Assessment of the characteristics of aggregates is the first aspect to be considered.

Acknowledgments The authors wish to thank the Fundação para a Ciência e Tecnologia (FCT) for the financial support under project GeoREMAT. The SEM images were performed at CEMUP. The equipment was funded by the projects REEQ/1062/CTM/2005 and REDE/1512/RME/2005 of FCT.

\section{References}

1. F. Granger, Vitruvius-On architecture, Books 1-5/6-10. (Harvard University Press, Cambridge, 1931), Loeb Classical 777 Library $(251 / 280)$, pp. $368-448$

2. J. Elsen, G. Martens, R. Snellings, Portland cement and other calcareous hydraulic binders: history, production and mineralogy, in Advances in the Characterization of Industrial Minerals, ed. by G.E. Christidis. EMU Notes in Mineralogy, vol 9 (Eötvös University Press, Budapest, 2010), pp. 441-479

3. P. Brune, The mechanics of imperial Roman concrete and the structural design of the Roman monuments. PhD thesis, University of Rochester, Rochester, 2011, 413 pp

4. M.D. Jackson, G. Vola, D. Všianský, J.P. Oleson, B. Scheetz, C. Brandon, R. Hohlfelder, Cement microstructures and durability in ancient Roman seawater concretes, in Historic Mortars, Characteristics and Tests, ed. by J. Valek, C. Groot, J. Hughes (RILEM, Springer, Berlin, 2012), pp. 49-76

5. M.D. Jackson, S.R. Chae, S.R. Mulcahy, C. Meral, R. Taylor, P. Li, A.M. Emwas, J. Moon, S. Yoon, G. Vola, H.R. Wenk, P.J.M. Monteiro, Unlocking the secrets of Al-tobermorite in Roman seawater concrete. Am. Mineral. 98, in press (2013)

6. G.C. Mays, The behaviour of concrete, in Durability of Concrete Structures-Investigation, Repair, Protection, ed. by G.C. Mays. (E \& FN Spon, Chapman \& Hall, London, 1992), 267 pp

7. K.E. Peray, The Rotary Cement Kiln, 2nd edn. (Chemical Publishing Corporation, New York, 1986), 389 pp

8. H.F.W. Taylor, Cement Chemistry, 2nd edn. (Thomas Telford, London, 1997)

9. A.M. Neville, Properties of Concrete, 4th edn. (Pearson Education Limited, Essex, 1999), 844 pp

10. P.E. Stutzman, Microscopy of clinker and hydraulic cements. In: M.A.T.M. Broekmans, H. Pöllman (eds.), Applied mineralogy of cement and concrete. Rev. Mineral. Geochem. 74, 101-145 (2012)

11. R.H. Bogue, H.H. Steinour, Origin of the special chemical symbols used by cement chemists. J. Portland Cem. Assoc. 3(3), 20-21 (1961)

12. EN 206-1, Concrete-Part 1: Specification, Performance, Production and Conformity (CEN, Brussels, 2007)

13. M.A.G. Aranda, A.G. de la Torre, L. León-Reina, Rietveld quantitative phase analysis of OPC clinkers, cements and hydration products. In: M.A.T.M. Broekmans, H. Pöllman (eds.), Applied mineralogy of cement and concrete. Rev. Mineral. Geochem. 74, 169-209 (2012)

14. R. Snellings, G. Mertens, J. Elsen, Supplementary cementitious materials. In: M.A.T.M. Broekmans, H. Pöllman (eds.), Applied mineralogy of cement and concrete. Rev. Mineral. Geochem. 74, 211-278 (2012)

15. ACI Committee 221, State of the Art Report on Alkali Aggregate Reactivity, ACI 221.1R-98, 1998, $31 \mathrm{pp}$

16. B. Fournier, M.A. Bérubé, K.J. Folliard, M. Thomas, Report on the Diagnosis, Prognosis, and Mitigation of Alkali-Silica Reaction (ASR) in Transportation Structures. Federal Highways Administration, FHWA-HIF-09-004, 2010

17. D.W. Hobbs, Alkali-Silica Reaction in Concrete (Thomas Telford, London, 1988)

18. O. Çopuroğlu, The characterisation, improvement and modelling aspects of frost salt scaling of cement-based materials with a high slag content. Unpublished PhD thesis, Technical University Delft, Delft, 2006, 188 pp 
19. D.S. Leek, The passivity of steel in concrete. Q. J. Eng. Geol. 24, 55-66 (1991)

20. I. Fernandes, M.A.T.M. Broekmans, F. Noronha, Petrography and geochemical analysis for the forensic assessment of concrete damage, in Criminal and Environmental Soil Forensics, chap 11, ed. by K. Ritz, L. Dawson, D. Miller (Springer, New York, 2008), pp 163-180

21. L. Bertolini, B. Elsener, P. Pedeferri, R. Polder, Corrosion of Steel in Concrete, Prevention, Diagnosis, Repair (Wiley, Weinheim, 2004), $409 \mathrm{pp}$

22. W.A. Segers, M.A.T.M. Broekmans, Reflectometric impulse measurement technique. Land + Water 34(2), 48-49 (1994) (in Dutch)

23. J. Skalny, J. Marchand, I. Odler, Sulfate Attack on Concrete. Modern Concrete Technology Series 10 (Spon Press, London, 2002), $217 \mathrm{pp}$

24. H.F.W. Taylor, Sulfate reactions in concrete-microstructural and chemical aspects, in Cement Technology, ed. by E.M. Gartner, H. Uchikawa. American Ceramic Society, Ceramic Transactions, vol 40 (American Ceramic Society, Westerville, 1994), pp. $61-78$

25. P. Hagelia, Deterioration mechanisms and durability of sprayed concrete for rock support in tunnels. Unpublished $\mathrm{PhD}$ thesis, Technical University of Delft, Delft, 2011, 205 pp + appendices

26. F. Mittermayr, Why thaumasite is forming in concrete structures. $\mathrm{PhD}$ thesis, Graz University of Technology (TUG), Graz, 2012, $120 \mathrm{pp}$

27. S. Diamond, Alkali Aggregate Reactions in Concrete: An Annotated Bibliography, 1939-1991. Strategic Highway Research Program Report (SHRP-C/UWP-92-601), 1992, 465 pp

28. G. Blight, M. Alexandre, Alkali-Aggregate Reaction and Structural Damage to Concrete (Taylor \& Francis, Balkema, 2011), $229 \mathrm{pp}$

29. M.A.T.M. Broekmans, Deleterious reactions of aggregate with alkalis in concrete. In: M.A.T.M. Broekmans, H. Pöllman (eds.), Applied mineralogy of cement and concrete. Rev. Mineral. Geochem. 74, 279-364 (2012)

30. B. Godard, M. deRooij, J.G.M. Wood (eds.), RILEM AAR-6.1, Guide to Diagnosis and Appraisal of AAR Damage to Concrete in Structures-Part 1-Diagnosis (RILEM, Springer, Berlin, 2013)

31. J. Lindgård, O. Andiç-Çakır, I. Fernandes, D.M.A. Thomas, T.F. Rønning, Alkali-silica reactions (ASR): literature review on parameters influencing laboratory performance testing. Cem. Concr. Res. 42, 223-243 (2012)

32. CUR-Recommendation 89, Measures to Prevent Concrete Damage by the Alkali-Silica Reaction, Official English translation, 2nd revised edition (Centre for Civil Engineering Research and Codes, Gouda, 2008), $48 \mathrm{pp}$

33. J. Lindgård, Ö. Andiç-Çakir, I. Borchers, M. Broekmans, E. Brouard, I. Fernandes, C. Giebson, B. Pedersen, C. Pierre, T.F. Rønning, M.D.A. Thomas, B.J. Wigum, RILEM TC219-ACS-P: Literature Survey on Performance Testing. COIN Project Report, vol 27, 2011, $164 \mathrm{pp}$

34. C. Larive, A. Laplaud, O. Coussy, The role of water in alkalisilica reaction, in Proceedings of the 11th International Conference on Alkali-Aggregate Reaction in Concrete, Québec City, 2000, ed. by M.A. Bérubé, B. Fournier, B. Durand, pp. 61-69

35. A. Leemann, B. Lothenbach, The influence of potassium-sodium ratio in cement on concrete expansion due to alkali-aggregate reaction. Cem. Concr. Res. 38, 1162-1168 (2008)

36. A.B. Poole, Introduction to alkali-aggregate reaction in concrete, in The Alkali-Silica Reaction in Concrete, ed. by R.N. Swamy (Blackie and Son, London, 1992), 333 pp

37. D.W. Hadley, Field and laboratory studies on the reactivity of sand-gravel aggregates. J. Portland Cem. Assoc. Res. Dev. Lab. 3, 17-33 (1968)
38. D.C. Stark, Alkali-silica reactivity in the Rocky Mountain Region, in Proceedings of the 4th International Conference on the Effects of Alkalis in Cement and Concrete, Purdue University, June, 1978, pp. 235-243

39. D.C. Stark, Alkali-silica reactivity: some reconsiderations. Cem. Concr. Aggreg. 2(2), 92-94 (1980)

40. L.H. Tuthill, Performance failures of concrete materials and of concrete as a material. ACI Concr. Intern. 2(1), 33-39 (1980)

41. M.A. Ozol, D.O. Dusenberry, Deterioration of Precast Panels with Crushed Quartz Coarse Aggregate due to Alkali-Silica Reaction, SP-131 (American Concrete Institute, Farmington Hills, 1992), pp. 407-415

42. D. Stark, M.S.Y. Bhatty, Alkali Silica Reactivity: Effect of Alkali in Aggregate on Expansion, STP 930 (ASTM International, West Conshohocken, 1985), pp 16-30

43. S. Diamond, J.L. White, W.L. Dolch, Transformation of clay minerals by calcium hydroxide attack, in , Proceedings of the 12th National Conference on Clays and Clay Minerals, Atlanta, 1964, ed. by E. Ingerson, pp. 359-379

44. M.A. Bérubé J. Locat, M. Choquette, B. Fournier, Beneficial lime stabilization of clay soils and deleterious alkali-aggregate reactions in concrete: two phenomena related to the chemical stability of minerals at high $\mathrm{pH}$ and in presence of $\mathrm{Ca}\left(\mathrm{OH}_{2}\right)$, in Proceedings of the 41st Conference on Canadian Geotechnical Society, Waterloo/Kitchener, 1988, pp. 150-159

45. M.A. Bérubé, J. Duchesne, J.F. Dorion, M. Rivest, Laboratory assessment of alkali contribution by aggregates to concrete and application to concrete surfaces affected by alkali-silica reactivity. Cem. Concr. Res. 32, 1215-1227 (2002)

46. M. Choquette, M.A. Bérubé, J. Locat, Mineralogical and microtextural changes associated with lime stabilization of marine clays from Eastern Canada. Appl. Clay Sci. 2, 215-232 (1987)

47. M. Choquette, M.A. Bérubé, J. Locat, Behavior of common rockforming minerals in a strongly basic $\mathrm{NaOH}$ solution. Can. Mineral. 29, 163-173 (1991)

48. D. Constantiner, S. Diamond, Alkali release from feldspars into pore solutions. Cem. Concr. Res. 33, 549-554 (2003)

49. M.A. Bérubé, B. Fournier, Alkalis releasable by aggregates in concrete: significance and test methods. In: M. Tang, M. Deng (eds.), Proceedings of the 11th International Conference on Alkali-Aggregate Reaction on Concrete, Beijing, 2004, pp. $17-30$

50. B. Pedersen, Alkali-reactive and inert fillers in concrete. Rheology of fresh mixtures and expansive reaction. $\mathrm{PhD}$ Thesis, Norwegian University of Science and Technology (NTNU), Trondheim, 2004 (2004/92): 198 pp + 48 pp (appendices)

51. J. Lindgård, P.J. Nixon, I. Borchers, B. Schouenborg, B.J. Wigum, M. Haugen, U. Åkesson, The EU "PARTNER" ProjectEuropean standard tests to prevent alkali reactions in aggregates: final results and recommendations. Cem. Concr. Res. 40, 611-635 (2010)

52. V. Jensen, Alkali aggregate reaction in southern Norway. Doctor Technical Thesis, The Norwegian Institute of Technology, University of Trondheim, Trondheim, 1993, $262 \mathrm{pp}$

53. BRE Digest 330, Alkali Aggregate Reactions in Concrete. Building Research Establishment, London, 2004, 22 pp

54. I. Sims, Alkali-silica reaction-UK experience, in The AlkaliSilica Reaction in Concrete. ed by R.N. Swamy (Blackie and Son, London, 1992), 333 pp

55. N. Louarn, C. Larive, Alcali-réaction et réaction sulfatique: synthèse des études microscopiques d'expertises de ponts dégradés (Alkali-silica reaction and sulphate attack: synthesis of microcopic study and expertise in degraded bridges). Bull. LPC 184, 57-69 (1993) (in French)

56. C. Larive, Apports combinés de l'expérimentation et de la modélisation à la compréhension de l'alcali-réaction et de ses 
effets mécaniques (Combined contributions of experimentation and modelling for the understanding of alkali-silica reactions and their mechanical effects). Etudes et recherches des Laboratoires des Ponts et Chaussées, 0A28, LCPC, Décembre, 1998, 402 pp (in French)

57. S. Nishibayashi, K. Okada, M. Kawamura, K. Kobayhashi, T. Kojima, T. Miyagawa, K. Nakano, K. Ono, Alkali-silica reaction-Japanese experience, in The Alkali-Silica Reaction in Concrete, R.N. Swamy (Blackie and Son, London, 1992), 333 pp

58. D.A. St. John, Alkali-aggregate reaction-New Zealand experience, in The Alkali-Silica Reaction in Concrete, R.N. Swamy (Blackie and Son, London, 1992), 333 pp

59. M.A.T.M. Broekmans, The alkali-silica reaction: mineralogical and geochemical aspects of some Dutch concretes and Norwegian mylonites. PhD thesis, University of Utrecht, Geologica Ultraiectina, Utrecht, vol 217, 2002, $144 \mathrm{pp}$

60. BCA, The Diagnosis of Alkali-Silica Reaction. Report of a working party, British Cement Association Publication 45.042, 1992, $44 \mathrm{pp}$

61. H. Pyy, E. Holt, M. Ferreira, An Initial Survey on the Occurrence of Alkali Aggregate Reaction in Finland. Customer Report VTT-CR-00554-12। 29.2.2012, 2012

62. D.A. St. John, A.B. Poole, I. Sims, Concrete Petrography: A Handbook of Investigative Techniques, 1st edn. (Arnold Publishers, London, 1998) 